\title{
The Impact of COVID-19 in Brazil: Labour Market and Social Protection Responses
}

\author{
Ian Prates ${ }^{1,2} \cdot$ Rogério J. Barbosa ${ }^{3}$ \\ Published online: 10 September 2020 \\ (C) Indian Society of Labour Economics 2020
}

\section{Introduction}

The social and economic crisis triggered by the COVID-19 pandemic pushed $83.5 \%$ of the labour market in Brazil into a state of vulnerability (Barbosa et al. 2020a; Prates and Barbosa 2020). And even with emergency policies, we estimate that at least 26 million workers (over a quarter of the economically active population) will not have access to any compensation: whether unemployment insurance, EBI (Emergency Basic Income), or right to a significant withdrawal from their workers' fund (Length-of-Service Guarantee Fund). All that is left for them is bankruptcy, layoffs, or the emergency assistance programme for formally registered workers.

Like many other developing countries, however, Brazil was already suffering from a state of emergency prior to the COVID-19 pandemic. But in the Brazilian case, a poor recovery from the 2015-16 economic crisis alongside the new coronavirus epidemic combined to create the perfect storm.

At the beginning of 2020, Brazil had $12.6 \%$ unemployment, 5\% hidden unemployment due to discouragement, $40 \%$ informality, and rapidly rising inequality. For the bottom half of the social pyramid, the 2015 crisis never ended. Since then, the poorest population has experienced income losses every year. Targeted transfer programmes have had no countercyclical effect (Barbosa et al. 2020b). Systematic budget cuts in the Bolsa Família Programme have resulted in a drop in the number of beneficiaries as well as in the average amount transferred. This has led to an increase in the queue for entry to the programme (people who meet the eligibility criteria but are not incorporated). To a large extent, the persistence of poverty results from the dismantling of social policies after 2015.

Poverty and informality, ever-increasing since then, bear witness.

Ian Prates

ianprates@cebrap.org.br

1 Brazilian Center for Analysis and Planning (CEBRAP), São Paulo, Brazil

2 Social Accountability International (SAI), New York, USA

3 Center for Metropolitan Studies, University of São Paulo (USP - Brazil), São Paulo, Brazil 


\subsection{COVID-19 and the impacts on social protection and the labour market}

The pandemic arrived with devastating effects. Data from the Ministry of Economy show a negative balance of more than 1 million formal jobs between March and April. In total, there was an increase of 4.9 million in the numbers of unemployed persons. Furthermore, until May 26, working hours and wages were reduced for 8.1 million workers under a special programme for the formal labour market. ${ }^{1}$ More than half of these labour agreements were for the complete suspension of employment contracts.

The official unemployment rate in May was $10.1 \%$, slightly smaller than in January and February. However, if we also take into account the contingent of people who couldn't search for a job specifically due to the pandemic (and the social distancing policies), ${ }^{2}$ that number rises to $25.4 \%$. If there had not been any government assistance whatsoever, household per capita income would have dropped by $\mathrm{R} \$ 66$ (5.0\%) and the poverty rate would have risen from 18.7 to $21.9 \%$ of the population (Barbosa and Prates 2020).

The Emergency Basic (EBI) Income Programme eased the impact on the average income of informal workers and the poorest families. It is an unconditional cash transfer of $600 \mathrm{BRL}$, initially for 3 months, which was instituted in by the federal law No. 13.982/2020. However, situations of poverty involve a multitude of dimensions not fully captured solely by income: bad housing conditions, lack of access to public services, more exposure to violence and crime, insecure jobs, etc. These dimensions are not tackled by a short-term cash transfer. And the money received certainly does not make up for the deaths from COVID-19, greater among the poorest. In other words, poverty rates, measured as income insufficiency, become less correlated to and an inadequate proxy for the real multidimensional poverty. We should also heed warning of the transient or temporary nature of these transfers: after the emergency benefit ends, we immediately return to the desolate scenario created by the pandemic.

While the EBI is an essential measure, it leaves out a large share of the population located in the "middle" of the income distribution. Some of these individuals are constantly transiting between formality and informality, going in and out of poverty: any static photograph would categorically place them on one side or the other (however, like Schrödinger's cat, they live in a quantum superposition of states). Another group is the category we call the "new vulnerable": formal workers who, under usual conditions (or even in crises), would not be at risk, but were hit hard by economic downturns and/or wage reduction agreements.

As a result, it is possible that this unprotected middle class has been enduring losses without any compensation. A possible counterintuitive consequence may be the reduction of income inequality: the economically impacted middle class

\footnotetext{
1 The Emergency Program for Maintenance of Employment and Income was created by a presidential decree, the Provisory Measure 936, in 1st April 2020.

${ }^{2}$ These are individuals who declared wanting to work and being available for assuming a position immediately, if they find a job.
} 
becomes more similar to the poorest strata. We have seen this happen before in Brazil in the early 1990s, albeit on a smaller scale. Inequality has always been a serious problem, but its solution cannot strive towards "equality in poverty".

The consequences of the crisis will be felt for a long time. If we do not implement a minimum income policy, broader than the current Bolsa Família, we run the risk of pushing a large share of people back into poverty and vulnerability: both those who had been temporarily shielded by the EBI, and the "middle" segment of the income distribution - the old and the new vulnerable.

In any case, the EBI has had positive impacts on economic circulation, even amidst a pandemic. Freire et al. (2020) argue that the benefit paid to the poorest population spreads, by way of consumption, to other families and income brackets-meaning it generates economic momentum during the crisis and allows for the collection of consumption and production taxes, feeding back into public finances. Without the EBI, Brazilian GDP would have plummeted even more in 2020.

The unavoidable need for social distancing to contain the disease sabotaged the ill-fated plans for growth and adjustment in 2020. Furthermore, social isolation policies in Brazil were extremely uncoordinated between the central government and the states (Barberia et al. 2020). On the one hand, President Jair Bolsonaro has never admitted the seriousness of the pandemic and has openly boycotted social isolation measures, going as far as contradicting the recommendations of the Ministry of Health. On the other hand, state governors have adopted more or less erratic measures, depending on their political alignment with the president.

At the international level, the initiatives towards regional integration throughout the 2000s have been shattered by the new right-wing governments in Latin America, less prone to south-south cooperation. Institutions created to reinforce and promote regional integration in the 2000s, such as CELAC (Community of Latin American and Caribbean States), are being left to their own devices (Prates and Lages [forthcoming]). And Brazil, as the continent's largest country, played a central role in this process, which ultimately stalled coordinated efforts between countries and aggravated the spread of the virus in the region. On the Brazilian side, collective actions to tackle the pandemic have been negatively affected both internally (the central government does not coordinate with the states), as well as at the international level, thus clearly hindering their effectiveness.

The truth remains that Brazil has done very little to contain the pandemic, and the consequences are devastating. The death toll has reached far higher levels than necessary, even though Brazil's public health system is renowned worldwide for its breadth, capillarity, and competence to deal with similar situations. ${ }^{3}$ It is no accident that the country has been extremely successful in fighting HIV, malaria, and the Zika virus. However, by undermining the central role of doctors, specialists, and scientists, President Jair Bolsonaro has transformed the Ministry of Health into no more than an adjunct in the fight against the pandemic.

\footnotetext{
3 Cf. https://economia.uol.com.br/noticias/reuters/2020/05/26/especial-bolsonaro-colocou-generais-paracombater-coronavirus-e-brasil-esta-perdendo-a-batalha.htm.
} 
Reopening the economy is not a solution. Abandoning containment measures prematurely may result in even greater damage; not to mention more deaths, of course. Unfortunately, there is no magic bullet. Extra domo nullasalus- "outside the home there is no salvation"-nor without basic income.

\section{The Pandemic and Beyond in Developing Countries}

We find ourselves in a unique opportunity to debate more solid basic income programmes; if not universal, at least broader. Income transfers focused solely on extreme poverty (such as Bolsa Família in Brazil), disregards the income volatility that affects almost two thirds of the population-a problem that has never been addressed by any social policy; a wound that reopens with each new instability. An emergency income is justifiable as we are not living in normal times. However, the "usual" situation in middle-income countries_-such as Brazil, India, South Africa, and many other Latin American, African, and Asian countries-remains deeply characterized by unjustifiable social ills, impelling us towards a permanent basic income.

A broader income programme, however, cannot replace other welfare and social policies-especially health, education, and social assistance services provided by the State. Otherwise, it would just mean a "voucherization" of social protection. On the contrary, it must be integrated into a broad social protection system to address the challenges imposed by the legacy of the pandemic, the impact of digitization on the labour market, and new forms of informality.

In this regard, we emphasize the vertiginous growth of the so-called "independent workers" all over the world. Unlike traditional informal and autonomous workers, "independents" undertake activities that are intermediated through the so-called on-demand platforms.

The International Labour Organization (ILO) has consistently reiterated that the platform economy can negatively affect the realization of the Fundamental Principles and Rights at Work laid out in 1998. In addition, work has become increasingly supervised (either physically or through artificial intelligence mechanisms) and characterized by a relationship of dependency with the client(s) (De Stefano 2019). But neither the consumers nor the "organizers" of the platforms recognize a labour relationship that would imply accountability for the workers' social security.

The effects of digitalization on labour and its regulation were already underway before the pandemic (Paus and Ford 2018). However, while this process was expedited for some occupations and activities, it has also become clear that there are inherent limits due to the nature of some occupations. Either way, the pandemic has unveiled potentialities but also limits to digitalization.

The unfolding scenario for the post-pandemic world is fraught with uncertainties. However, we must acknowledge that the promotion of well-being inevitably calls for solutions that coalesce the previous challenges posed to the future of labour (ILO) with the potential social tragedy that the pandemic has in store for us. Societies must, therefore, decide whether the legacy of the COVID-19 pandemic will be 
no more than a catastrophe; or an opportunity to change how policies address of millions of workers and families in poverty and vulnerability around the world.

Acknowledgements The author thanks São Paulo Research Foundation (Fapesp) for the financial support (Grant no. 2018/13863-0).

\section{References}

Barberia, Lorena G., Natalia de Paula Moreira, Maria Letícia Claro de F. Oliveira, Luiz Guilherme Roth Cantarelli, Fabiana da Silva Pereira, Isabel Seelaender, Marcela Mello Zamudio, and Pedro Schmalz. 2020. Lack of Coordination between the Federal Government and States Undermines Social Distancing Policies. Increased and Unregulated Relaxation Could Aggravate the Pandemic. Covid-19: Rede de Pesquisa Solidária Políticas Públicas \& Sociedade 4. https://redepesquisasol idaria.org/en/bulletins/bulletin-4/lack-of-coordination-between-the-federal-government-and-state s-undermines-social-distancing-policies-increased-and-unregulated-relaxation-could-aggravate-thepandemic/. Accessed 1 May 2020.

Barbosa, Rogério J., and Ian Prates. 2020. Efeitos Do Desemprego, Do Auxílio Emergencial e Do Programa Emergencial de Preservação Do Emprego e Da Renda (MP 936) Sobre a Renda, a Pobreza e a Desigualdade Durante e Depois Da Pandemia. https://papers.ssrn.com/sol3/papers.cfm?abstr act_id=3630693. Accessed 24 June 2020.

Barbosa, Rogério Jerônimo, Ian Prates, and Thiago Meireles. 2020a. The Vulnerability of Brazilian Workers amid the Covid-19 Pandemic. Covid-19: Rede de Pesquisa Solidária Políticas Públicas \& Sociedade. https://doi.org/10.13140/RG.2.2.18025.72803.

Barbosa, Rogério Jerônimo, Pedro Herculano Guimarães Ferreira de Souza, and Sergei Soares. 2020 b. Income Distribution During the 2010s: A Lost Decade in the Struggle Against Inequality and Poverty. Working Paper [mimeo]. Sao Paulo, Brazil.

De Stefano, Valerio. 2019. 'Negotiating the Algorithm': Automation, Artificial Intelligence and Labour Protection." Comparative Labour Law \& Policy Journal 41(1). https://papers.ssrn.com/sol3/paper s.cfm?abstract_id=3178233. Accessed 26 Aug 2020.

Freire, Débora, Edson Domingues, Aline Magalhães, Thiago Simonato, and Diego Miyajima. 2020. Renda Básica Emergencial: Uma Resposta Suficiente Para a Covid-19? Working Paper [mimeo]. Belo Horizonte, Brazil. https://pesquisas.face.ufmg.br/nemea/wp-content/uploads/sites/20/2020/05/ Nota_Tecnica_RBE_VF.pdf. Accessed 25 June 2020.

Paus, Eva, and Martin Ford (eds.). 2018. Confronting Dystopia: The New Technological Revolution and the Future of Work. Ithaca: ILR Press, an imprint of Cornell University Press.

Prates, Ian, and Rogério Jerônimo Barbosa. 2020. Black Men and Black Women Are the Most Vulnerable in the Crisis. However, a 'New Vulnerable' Group Emerges, White Men and White Women in NonEssential Services. Covid-19: Rede de Pesquisa Solidária Políticas Públicas \& Sociedade. https:// doi.org/10.13140/RG.2.2.34802.94402.

Prates, Ian, and Carolina Lages. [forthcoming]. The Brazilian Perception of China's Belt and Road Initiative. Journal of Belt and Road Studies. https://papers.ssrn.com/sol3/papers.cfm?abstract_id=36814 67. Accessed 26 Aug 2020.

Publisher's Note Springer Nature remains neutral with regard to jurisdictional claims in published maps and institutional affiliations. 